\title{
EFFECT OF AGE AND WHOLESALE CUTS ON THE QUALITY OF INDIGENOUS SHEEP CARCASS
}

\author{
M. A. Hamid, S. Akhter, S. M. E. Rahman and M. Khan
}

\begin{abstract}
The study was conducted to investigate the nutritive value and microbial status of different wholesale cuts of sheep carcass. The meat sample was obtained from 3 sheep. The ages of sheep were approximately of 1, 2 and 3 years. The wholesale cuts were shoulder, rack, loin and leg of each sheep carcass. The $\mathrm{pH}$, juiciness, chemical composition, total bacteria, coliform bacteria, yeast and mould were studied to assess the quality of meat. The range of $\mathrm{pH}$ value were $5.077-5.927$. The value of juiciness was decreased with the age. The value of dry matter, ash, crude protein, ether extract, calcium and phosphorus content of all samples were ranged from $23.32-30.40 \%, 0.88-1.027 \%, 20.50-24.88 \%, 8.10-12.13 \%, 0.012-0.038 \%$ and $0.048-0.185 \%$ respectively. Statistical analysis indicated that the value of $\mathrm{pH}$, juiciness, dry matter, crude protein, ether extract, calcium, phosphorus and yeast (log value) was highly significant $(\mathrm{P}<0.01)$ due to age and cut. Chemical composition, such as dry matter, ash, ether extract and calcium of all the samples increased gradually with the age, except crude protein, which decreased gradually with the age. The phosphorus content of the sample did not differ significantly due to age and cuts. The value of ash content was less significant $(\mathrm{P}<0.05)$ due to different cuts but highly significant $(\mathrm{P}<0.01)$ due to age. The range of total bacteria and coliform bacteria was 4.210-4.787 and 2.38-3.637/g of sample respectively. The range of yeast was $1.297-2.777 / \mathrm{g}$ of sample. Different meat cuts and ages did not show significant difference on total bacteria and coliform bacteria but in case of yeast, the value was highly significant $(\mathrm{P}<0.01)$ for the ages and cuts. Nutrient content of mutton varies due to different wholesale cuts as well as age.
\end{abstract}

Key words : Sheep carcass, Wholesale cuts, Microbial status

\section{Introduction}

The total sheep population in Bangladesh is estimated at about 1.04 million. Sheep represent $1.03 \%$ of the total livestock population in Bangladesh (FAO, 2000). Among the Livestock, sheep population is the lowest in Bangladesh. Landless and marginal farmers usually raise sheep. They are sparsely distributed all over the country but high density found in the districts of Rajshahi, Tangail and in the delta region of Noakhali (Rahman, 1989). Sheep is raised primarily for meat production. The most important characteristics of sheep is its prolificacy, lambing twice a year where twin is common (Rahman, 1989). It also revealed that $60.6 \%$ of the total meat came from cattle, $1.3 \%$ from buffalo, $8.1 \%$ from goat, $0.9 \%$ from sheep and $29.1 \%$ from chicken and duck. The approximate protein and fat content of lean meat from young bull are 22 and $2 \mathrm{~g}$ per $100 \mathrm{~g}$ of meat whereas these figures are 21 and 1 in case of calves. But incase of lamb the approximate protein and fat content are 21 and $3 \mathrm{~g}$ per $100 \mathrm{~g}$ of lean meat. Though there is little variation in quality of meat of different species

Department of Animal Science, Bangladesh Agricultural University, Mymensingh-2202, Bangladesh

(Received : May 10, 2008) 
Bang. J. Anim. Sci. 2008, 37 (1)

(Simonsen et al., 1988), there is variation in quality of meat according to age and sex within a species. The variation in quality of meat also exists among different parts of carcass of an individual (Yeates et al., 1975). Meat and meat products have continued to claim their share in the food market price because of their acceptable sensory characteristics. Meat palatability is dependent upon factors such as appearance, aroma, flavour, juiciness, tenderness and colour. Species, breed, sex, age, diet and carcass handling techniques influence the factors. The consumers prefer meat of different wholesale cuts on the basis of colour, odour, quality, age and microbial load of carcass. They want to pay different prices on the basis of such factor. According to Hossain et al. (1997) sheep industry has received no attention to improve quality and quantity of mutton and/or wool in Bangladesh. Sheep are raising and slaughtering in unplanned way like other ruminants. There is a dearth of information for local sheep of Bangladesh on carcass characteristics (Mazumder et al., 1998). However, there is no information about the quality (physical or chemical) and microbiological status of different wholesale cuts of indigenous sheep carcass. Thus, a systematic study is needed to determine the quality and microbiological status of different wholesale cuts of indigenous sheep carcass. The present study was therefore, undertaken to find out the composition of wholesale cuts of different age of sheep to determine the effect of age and cuts on the quality of mutton.

\section{Materials and Methods}

Twelve samples of mutton from different wholesale cuts of different ages (1,2 and 3 years) of sheep carcass were studied in this experiment.

\section{Collection and sample preparation}

Three sheep of 1, 2 and 3 years were slaughtered at 6 a.m. in central municipal slaughter house of Mymensingh town and flayed after half an hour. Shoulder, rack, loin and leg were separated from each sheep carcass and brought into the laboratory for processing. Then twelve samples of mutton of different ages and wholesale cuts were prepared for this experiment. Fat, bone and fascia were removed from the sample with the help of knife and fresh muscles were collected for the use of experiment. The meat sample washed properly and made water free pressing by hand.

\section{pH measurements}

Five grams of sample was homogenized with $10 \mathrm{ml}$ distilled water in a blender and the $\mathrm{pH}$ was measured using by $\mathrm{pH}$ meter (Corning model 250).

\section{Juiciness}

The size of the meat sample was usual table size (block) which we generally eat in our home. About $150 \mathrm{~g}$ of meat was prepared for juiciness. The meat sample was cooked for 15 minutes in a saucepan without mixing water. The weight of cooked meat was recorded. Then the final weight was deducted from the initial weight.

\section{Chemical composition}

Proximate composition such as dry matter (DM), ash, crude protein (CP) and ether extract (EE) were carried out according to the methods (AOAC, 1980).

\section{Calcium and $P$}

The P concentrations were estimated according to Olsen and Sommers (1982) and the Ca were content were determined by using flame photometer (Knudsen et al., 1982). 


\section{Microbial assessment}

For microbial assessment total bacterial count, coliform count, yeast count and mould count were undertaken. These parameters were determined according to APHA, 1998.

\section{Statistical analyses}

The study was conducted in a completely randomized design (CRD) and data were analyzed with the help of Mstat statistical computer package. The individual effects or interaction effects and LSD value were determined at 5 and $1 \%$ level of significance.

\section{Results and Discussion}

pH

The $\mathrm{pH}$ value was found highest in loin of 2 years sheep (5.927) and lowest in rack of 3 years sheep (5.077). The value was highly significant $(\mathrm{P}<0.01)$ among the cuts and ages (Table 1 and Table 2). The $\mathrm{pH}$ value of meat provides information about shelf life, tenderness, colour and water-holding capacity and indicates whether the animals have been exposed to stress prior to slaughter or not (Wiklund, 2005). The decrease in $\mathrm{pH}$ may be related with the production of lactic acid in post mortem muscle due to rigormortis process.

\section{Juiciness}

The juiciness was found highest in shoulder of 1 year $(41.25 \%)$ and lowest in loin of 3 years sheep $(34.80 \%)$. The value gradually decrease with the age (Table 2$)$. The value was highly significant $(\mathrm{P}<0.01)$ among the cuts and ages (Table 1 and Table 2). The degree of shrinkage on cooking is directly correlated with loss of juiciness to the palate (Siemers and Hanning, 1953). Good quality meat is juicier than that of poor quality. Juiciness reaches a minimum when the $\mathrm{pH}$ level of the meat is about 6 (Howard and Lawrie, 1956).

Table 1. Effect of cuts on different parameters

\begin{tabular}{|c|c|c|c|c|c|c|}
\hline \multirow{2}{*}{ Parameters } & \multicolumn{4}{|c|}{ Cuts } & \multirow{2}{*}{ LSD value } & \multirow{2}{*}{$\begin{array}{c}\text { Level of } \\
\text { significance }\end{array}$} \\
\hline & Shoulder & Rack & Loin & Leg & & \\
\hline $\mathrm{pH}$ value & $5.299^{\mathrm{c}}$ & $5.283^{\mathrm{c}}$ & $5.577^{\mathrm{b}}$ & $5.751^{\mathrm{a}}$ & 0.0884 & $* *$ \\
\hline Juiciness & $37.551^{\mathrm{c}}$ & $37.998^{b}$ & $36.917^{d}$ & $38.057^{\mathrm{a}}$ & 0.0884 & $* *$ \\
\hline DM & $25.689^{d}$ & $25.989^{c}$ & $26.750^{\mathrm{b}}$ & $26.917^{\mathrm{a}}$ & 0.1398 & $* *$ \\
\hline Ash & $0.963^{\mathrm{ab}}$ & $0.924^{\mathrm{b}}$ & $0.992^{\mathrm{a}}$ & $0.929^{\mathrm{b}}$ & 0.1083 & $*$ \\
\hline $\mathrm{CP}$ & $21.682^{\mathrm{c}}$ & $22.499^{\mathrm{a}}$ & $22.526^{\mathrm{a}}$ & $21.953^{\mathrm{b}}$ & 0.1978 & $* *$ \\
\hline $\mathrm{EE}$ & $11.694^{\mathrm{a}}$ & $10.694^{\mathrm{b}}$ & $10.718^{\mathrm{b}}$ & $10.553^{\mathrm{b}}$ & 0.4804 & $* *$ \\
\hline $\mathrm{Ca}$ & $0.020^{\mathrm{b}}$ & $0.024^{\mathrm{a}}$ & $0.022^{\mathrm{b}}$ & $0.020^{\mathrm{b}}$ & 0.0198 & $* *$ \\
\hline $\mathrm{P}$ & $0.165^{\mathrm{a}}$ & $0.158^{\mathrm{ab}}$ & $0.114^{\mathrm{b}}$ & $0.140^{\mathrm{ab}}$ & 0.0198 & $* *$ \\
\hline Total bacteria (log value) & 4.676 & 4.552 & 4.567 & 4.380 & - & NS \\
\hline Coliform bacteria (log value) & 2.699 & 2.896 & 3.042 & 2.758 & - & NS \\
\hline Yeast (log value) & $2.080^{\mathrm{a}}$ & $1.734^{\mathrm{c}}$ & $1.907^{\mathrm{b}}$ & $1.629^{\mathrm{d}}$ & 0.1876 & $* *$ \\
\hline
\end{tabular}

${ }^{\mathrm{NS}}$ Non Significant $(\mathrm{P}>0.05), *$ Significant at $5 \%$ level $(\mathrm{P}<0.05), * *$ Significant at $1 \%$ level $(\mathrm{P}<0.01)$

abcd Means with different superscripts within same row differ significantly $(\mathrm{P}<0.05)$ 
Bang. J. Anim. Sci. 2008, 37 (1)

\section{Dry matter}

The value was highest in loin of three years sheep (30.40\%) and lowest in shoulder of one year sheep (23.32\%). The values gradually increase with the age (Table 3 ).

The value was highly significant $(\mathrm{P}<0.01)$ among the cuts and ages (Table 1 and Table 2). The increase of dry matter content follows the decrease of moisture content. The current result also resemble with that of Robelin et al. (1977) who studied on the changes in chemical composition of 20 male lambs up to 16 weeks of age. They found that moisture content decreased significantly with the age.

Table 2. Effect of ages on different parameters

\begin{tabular}{|c|c|c|c|c|c|}
\hline \multirow{2}{*}{ Parameters } & \multicolumn{3}{|c|}{ Ages (year) } & \multirow{2}{*}{ LSD value } & \multirow{2}{*}{$\begin{array}{c}\text { Level of } \\
\text { significance }\end{array}$} \\
\hline & 1 & 2 & 3 & & \\
\hline $\mathrm{pH}$ value & $5.411^{\mathrm{b}}$ & $5.616^{\mathrm{a}}$ & $5.406^{\mathrm{b}}$ & 0.0589 & $* *$ \\
\hline Juiciness & $40.988^{a}$ & $36.532^{\mathrm{b}}$ & $35.371^{\mathrm{c}}$ & 0.0589 & $* *$ \\
\hline $\mathrm{DM}$ & $24.329^{\mathrm{c}}$ & $26.200^{\mathrm{b}}$ & $28.479^{\mathrm{a}}$ & 0.0932 & $* *$ \\
\hline Ash & $0.908^{\mathrm{b}}$ & $0.946^{\mathrm{b}}$ & $1.003^{\mathrm{a}}$ & 0.0722 & $* *$ \\
\hline $\mathrm{CP}$ & $23.705^{\mathrm{a}}$ & $21.886^{\mathrm{b}}$ & $20.904^{\mathrm{c}}$ & 0.1318 & $* *$ \\
\hline $\mathrm{EE}$ & $9.224^{\mathrm{b}}$ & $11.675^{\mathrm{a}}$ & $11.846^{\mathrm{a}}$ & 0.3202 & $* *$ \\
\hline $\mathrm{Ca}$ & $0.019^{\mathrm{b}}$ & $0.022^{b}$ & $0.023^{\mathrm{a}}$ & 0.0132 & $* *$ \\
\hline $\mathrm{P}$ & $0.163^{\mathrm{a}}$ & $0.126^{\mathrm{b}}$ & $0.143^{\mathrm{ab}}$ & 0.0132 & $* *$ \\
\hline Total bacteria (log value) & 4.554 & 4.629 & 4.447 & - & NS \\
\hline Coliform bacteria (log value) & 3.072 & 2.728 & 2.726 & - & NS \\
\hline Yeast (log value) & $1.849^{\mathrm{b}}$ & $1.569^{\mathrm{c}}$ & $2.094^{\mathrm{a}}$ & 0.1250 & $* *$ \\
\hline
\end{tabular}

NS Non significant $(\mathrm{P}<0.05)$,** Significant at $1 \%$ level $(\mathrm{P}<0.01)$

${ }^{a b c}$ Means with different superscripts within same row differ significantly $(\mathrm{P}<0.05)$

Ash

The highest ash value was found in loin of 3 years sheep (1.06\%) and lowest in shoulder of 1 year $(0.88 \%)$. The values gradually increase with the age (Table 2$)$. The value was less significant $(\mathrm{P}<0.05)$ among the cuts and highly significant $(\mathrm{P}<0.01)$ among the age (Table 1 and 2$)$ respectively. The result obtained from the present study are in agreement with Robelin et al. (1977), who studied on the changes in chemical composition of 20 male lambs up to 16 weeks of age. They found that ash content increased gradually with the age.

\section{Crude protein}

The value was highest in loin of 1 year sheep (24.88\%) and lowest in leg of 3 years sheep (20.50\%). The value was highly significant $(\mathrm{P}<0.01)$ among the cuts and ages (Table 1 and Table 2$)$. The values gradually decrease with the age (Table 2), which agrees with the study of Ray and Kromann, (1971), they found $15.7 \% \mathrm{CP}$ in 30 days feeding trial where as $14.5 \% \mathrm{CP}$ in 90 days feeding trial. 
Table 3. Combined effect of cuts and ages on different parameters

\begin{tabular}{|c|c|c|c|c|c|c|}
\hline \multirow{2}{*}{ Parameters } & \multirow{2}{*}{ Cuts } & \multicolumn{3}{|c|}{ Ages (years) } & \multirow{2}{*}{ LSD value } & \multirow{2}{*}{$\begin{array}{c}\text { Level of } \\
\text { significance }\end{array}$} \\
\hline & & 1 & 2 & 3 & & \\
\hline \multirow{4}{*}{$\mathrm{pH}$} & Shoulder & $5.40^{\mathrm{a}}$ & $5.25^{\mathrm{b}}$ & $5.25^{\mathrm{b}}$ & 0.1094 & $* *$ \\
\hline & Rack & $5.38^{\mathrm{a}}$ & $5.40^{\mathrm{a}}$ & $5.08^{\mathrm{b}}$ & 0.1895 & $* *$ \\
\hline & Loin & $5.40^{\mathrm{b}}$ & $5.93^{\mathrm{a}}$ & $5.40^{\mathrm{b}}$ & 0.1548 & $* *$ \\
\hline & Leg & $5.47^{\mathrm{b}}$ & $5.89^{\mathrm{a}}$ & $5.89^{\mathrm{a}}$ & 0.1094 & $* *$ \\
\hline \multirow{4}{*}{ Juiciness } & Shoulder & $41.25^{\mathrm{a}}$ & $36.35^{\mathrm{b}}$ & $35.05^{\mathrm{c}}$ & 0.1895 & $* *$ \\
\hline & Rack & $40.99^{\mathrm{a}}$ & $37.41^{\mathrm{b}}$ & $35.60^{\mathrm{c}}$ & 0.2189 & $* *$ \\
\hline & Loin & $40.64^{\mathrm{a}}$ & $35.31^{\mathrm{b}}$ & $34.80^{\mathrm{c}}$ & 0.1548 & $* *$ \\
\hline & Leg & $41.08^{\mathrm{a}}$ & $37.06^{\mathrm{b}}$ & $36.03^{\mathrm{c}}$ & 0.1094 & $* *$ \\
\hline \multirow{4}{*}{$\mathrm{DM}$} & Shoulder & $23.32^{\mathrm{c}}$ & $24.75^{\mathrm{b}}$ & $29.00^{\mathrm{a}}$ & 0.2447 & $* *$ \\
\hline & Rack & $24.90^{\mathrm{c}}$ & $25.95^{\mathrm{b}}$ & $27.12^{\mathrm{a}}$ & 0.2189 & $* *$ \\
\hline & Loin & $23.70^{\mathrm{c}}$ & $26.15^{\mathrm{b}}$ & $30.40^{\mathrm{a}}$ & 0.2447 & $* *$ \\
\hline & Leg & $25.40^{\mathrm{c}}$ & $27.95^{\mathrm{a}}$ & $27.40^{\mathrm{b}}$ & 0.2447 & $* *$ \\
\hline \multirow{4}{*}{ Ash } & Shoulder & $0.89^{\mathrm{b}}$ & $0.98^{\mathrm{b}}$ & $1.03^{\mathrm{a}}$ & 0.1548 & $*$ \\
\hline & Rack & $0.95^{\mathrm{a}}$ & $0.90^{\mathrm{c}}$ & $0.92^{\mathrm{b}}$ & 0.1548 & $*$ \\
\hline & Loin & $0.88^{\mathrm{b}}$ & $0.94^{\mathrm{ab}}$ & $1.06^{\mathrm{a}}$ & 0.2680 & $*$ \\
\hline & Leg & $0.90^{\mathrm{b}}$ & $0.89^{\mathrm{b}}$ & $1.00^{\mathrm{a}}$ & 0.1094 & $*$ \\
\hline \multirow{4}{*}{$\mathrm{CP}$} & Shoulder & $22.17^{\mathrm{a}}$ & $21.98^{\mathrm{b}}$ & $20.90^{\mathrm{c}}$ & 0.2189 & $* *$ \\
\hline & Rack & $24.51^{\mathrm{a}}$ & $21.97^{\mathrm{b}}$ & $21.02^{\mathrm{c}}$ & 0.2680 & $* *$ \\
\hline & Loin & $24.88^{\mathrm{a}}$ & $21.50^{\mathrm{b}}$ & $21.20^{\mathrm{b}}$ & 0.5686 & $* *$ \\
\hline & Leg & $23.26^{\mathrm{a}}$ & $22.10^{\mathrm{b}}$ & $20.50^{\mathrm{c}}$ & 0.2447 & $* *$ \\
\hline \multirow{4}{*}{$\mathrm{EE}$} & Shoulder & $11.00^{\mathrm{b}}$ & $11.95^{\mathrm{a}}$ & $12.13^{\mathrm{a}}$ & 1.1937 & $* *$ \\
\hline & Rack & $8.77^{\mathrm{b}}$ & $11.48^{\mathrm{a}}$ & $11.83^{\mathrm{a}}$ & 0.6093 & $* *$ \\
\hline & Loin & $8.10^{\mathrm{b}}$ & $12.03^{\mathrm{a}}$ & $12.02^{\mathrm{a}}$ & 0.8547 & $* *$ \\
\hline & Leg & $9.00^{\mathrm{b}}$ & $11.23^{\mathrm{a}}$ & $11.40^{\mathrm{a}}$ & 0.6093 & $* *$ \\
\hline \multirow{4}{*}{$\mathrm{Ca}$} & Shoulder & $0.0220^{\mathrm{a}}$ & $0.0220^{\mathrm{a}}$ & $0.0165^{\mathrm{b}}$ & 0.0692 & $* *$ \\
\hline & Rack & $0.0160^{\mathrm{b}}$ & $0.0165^{\mathrm{b}}$ & $0.0380^{\mathrm{a}}$ & 0.0599 & $* *$ \\
\hline & Loin & $0.0162^{\mathrm{b}}$ & $0.0380^{\mathrm{a}}$ & $0.0115^{\mathrm{c}}$ & 0.0489 & $* *$ \\
\hline & Leg & $0.0221^{\mathrm{b}}$ & $0.0115^{\mathrm{c}}$ & $0.0270^{\mathrm{a}}$ & 0.0363 & $* *$ \\
\hline \multirow{4}{*}{$\mathrm{P}$} & Shoulder & $0.17^{\mathrm{b}}$ & $0.19^{\mathrm{a}}$ & $0.14^{\mathrm{c}}$ & 0.0395 & $* *$ \\
\hline & Rack & $0.16^{\mathrm{b}}$ & $0.14^{\mathrm{c}}$ & $0.17^{\mathrm{a}}$ & 0.0379 & $* *$ \\
\hline & Loin & $0.15^{\mathrm{a}}$ & $0.05^{\mathrm{c}}$ & $0.14^{\mathrm{b}}$ & 0.0363 & $* *$ \\
\hline & Leg & $0.16^{\mathrm{a}}$ & $0.13^{\mathrm{b}}$ & $0.12^{\mathrm{c}}$ & 0.0346 & $* *$ \\
\hline \multirow{4}{*}{ Total bacteria (log value) } & Shoulder & 4.72 & 4.73 & 4.58 & - & NS \\
\hline & Rack & 4.79 & 4.49 & 4.38 & - & NS \\
\hline & Loin & 4.50 & 4.74 & 4.46 & - & NS \\
\hline & Leg & 4.21 & 4.56 & 4.37 & - & NS \\
\hline \multirow{4}{*}{ Coliform bacteria (log value) } & Shoulder & 2.73 & 2.56 & 2.80 & - & NS \\
\hline & Rack & 2.77 & 3.16 & 2.75 & - & NS \\
\hline & Loin & 3.64 & 2.81 & 2.68 & - & NS \\
\hline & Leg & 3.15 & 2.38 & 2.75 & - & NS \\
\hline \multirow{4}{*}{ Yeast (log value) } & Shoulder & $2.16^{\mathrm{b}}$ & $1.48^{\mathrm{c}}$ & $2.60^{\mathrm{a}}$ & 0.3095 & ** \\
\hline & Rack & $1.48^{\mathrm{c}}$ & $2.02^{\mathrm{a}}$ & $1.70^{\mathrm{b}}$ & 0.1094 & $* *$ \\
\hline & Loin & $1.47^{\mathrm{b}}$ & $1.48^{\mathrm{b}}$ & $2.78^{\mathrm{a}}$ & 0.5790 & $* *$ \\
\hline & Leg & $2.29^{\mathrm{a}}$ & $1.30^{\mathrm{b}}$ & $1.30^{\mathrm{b}}$ & 0.1094 & $* *$ \\
\hline
\end{tabular}

NS Non significant $(\mathrm{P}<0.05)$, Significant at $5 \%$ level $(\mathrm{P}<0.05)$, ** Significant at $1 \%$ level $(\mathrm{P}<0.01)$

${ }^{a b c}$ Means with different superscripts within same row differ significantly $(\mathrm{P}<0.05)$ 
Bang. J. Anim. Sci. 2008, 37 (1)

\section{Ether extract}

The highest value was in shoulder of 3 years sheep (12.13\%) and lowest in loin of 1 year sheep $(8.10 \%)$. The value was highly significant $(\mathrm{P}<0.01)$ among the cuts and ages (Table 2 and Table 3 ). The value was increased with the age (Table 2), which agrees with the study of Ray and Kromann, (1971), they found $20.9 \% \mathrm{EE}$ in 30 days feeding trial where as $26.9 \% \mathrm{EE}$ in 90 days feeding trial.

\section{Calcium}

The highest value was found in loin of 2 years and rack of 3 years sheep $(0.038 \%)$. The lowest value was in leg of 2 years and loin of 3 years sheep $(0.012 \%)$. The value gradually increased with the age (Table 2). The value was highly significant $(\mathrm{P}<0.01)$ among the cuts and ages (Table 2 and Table 2 ). Muscle itself is a poor source of calcium. However, mutton contains more calcium than beef; but, of course, from the nutritional viewpoint meat is not regarded as the principal source of calcium (R.A. Lawrie, 1979).

\section{Phosphorus}

The highest value of phosphorus was in shoulder of 2 years sheep $(0.185 \%)$ and lowest was in loin of same age $(0.048 \%)$. The results show that there was no specific trend (increasing or decreasing) among the Phosphorus content of the sample according to the age (Table 2). The value was highly significant $(\mathrm{P}<0.01)$ among the cuts and ages (Table 1 and Table 2$)$.

\section{Microbial load (log value) /g of sample}

The highest bacterial count were found in rack of 1 year sheep (4.787) and lowest were found in leg of same age (4.210). The coliform bacteria were highest in loin of 1 year sheep (3.637) and lowest in leg of 2 years sheep (2.380). On the other hand, the highest yeast was found in loin of 3 years sheep (2.777) and lowest in leg of 2 years (1.297). Incase of total bacteria and coliform bacteria there was no significant difference $(\mathrm{P}>0.05)$ among the ages and cuts (Table 2 and 3$)$. On the other hand, in case of yeast, the value was highly significant $(\mathrm{P}<0.01)$ among the ages and cuts.

\section{Combined effect of cuts and age}

The combine effect of ages and cuts are presented in Table 3 . The value of $\mathrm{pH}$, juiciness, dry matter, ash, crude protein, ether extract, calcium and phosphorus showed significant difference $(\mathrm{P}<0.05)$ due to the interaction effect of ages and cuts (Table 3 ). The total bacteria and coliform bacteria showed no significant difference $(\mathrm{P}>0.05)$. However, there was significant difference $(\mathrm{P}<0.01)$ in yeast value. It may be due to the health condition of the sheep, nutritional status of the diet, hygienic condition of the abattoir or contamination during handling.

\section{Conclusion}

From the present study it can be concluded that the nutrient content of the sheep carcass varies due to different wholesale cuts as well as age.

\section{Literature Cited}

AOAC Association of Official Analytical Chemists. 1980. Horwitz, N. (ed.), Official Methods of Analysis, $13^{\text {th }}$ ed., Washington DC, 957 pp. 
APHA (American Public Health Association). 1998. Standard Methods for the Examination of Dairy Products. $20^{\text {th }}$ edn. APHA. Inc. New York.

FAO (Food and Agriculture Organization of the United Nations). 2000. Production Year Book, Rome, Italy. $54: 211-215$.

Hossain, M. M., Hashem, M. A. and Hossain, M. S. 1997. Relationship of Carcass and Non-carcass Parameters with Live Weight of Sheep. Bang. J. Anim. Sc. 26(1-2) : 39-44.

Howard, A. and Lawrie, R. A. 1956. Spec. Rept. Fd. Invest. Bd., Lond., No. 63.

Kauffman, R. G., Carpenter, L., Bray, R. W. and Hoekstra, W. G. 1964. Biochemical properties of pork and their relationship to quality. II. Intramuscular fat. J. Food Sci. 29 : 70-74.

Knudsen, D., Peterson, G. A. and Part, P. F. 1982. Lithium and Potassium. In Methods of Soil Analysis, part 2 ( $2^{\text {nd }}$ edn.). A. L. Page, R.H. Miller, and D.R. Keeney (eds.), pp. 225-246. Amer. Soc. Agron., Inc. and Soil Sci. Soc. Amer., Inc., Madison, Wisconsin. USA.

Lawrie, R. A. 1979. Meat Science, ed. third. pp. 371.

Mazumder, M. A. R., Hossain, M. M. and Akhter, S. 1998. Effect of levels of concentrate supplementation on liveweight gain and carcass characteristics in sheep on restricted grazing. AJAS. 11(1) : 17-20.

Olsen, S. R. and Sommens, L. E. 1982. Phosphorus. In Methods of Soil Analysis, Part 2 ( $2^{\text {nd }}$ edn. $)$. A. L. Page, R.H. Miller, and D.R. Keeney (eds.), pp. 403-427. Amer. Soc. Agron., Inc. and Soil Sci. Soc. Amer., Inc., Madison, Wisconsin. USA.

Rahman, M. M. 1989. Sheep production and development in Bangladesh. Proceeding of the workshop on sheep production in Asia. PCARRD. Los Banos. Philippines. pp. 81-95.

Ray, E.E. and Kromann, R. P. 1971. Effect of sex, age of lamb and length of feeding upon energy metabolism and carcass traits of lambs. J. Anim. Sci. 32 : 721-726.

Robelin, J., Therie, M., Arnal, M. and Ferrara, M. 1977. Changes in the chemical composition of male lambs of up to 16 weeks of age. Annales de Zootechie. 26 (1) : 69-81.

Siemers, L. L. and Hanning, F. 1953. Food. Res. 18, 113.

Simonsen, B., Hamm, R. and Rogowski, B. 1988. Meat as food. meat science, milk science and technology. In : World Animal Science, Disciplinary Approach. B (3) : 115-139.

Wiklund, E. 2005. Carcass treatments for improved meat quality. Rangifer Report. (10) : 99-103.

Yeates, N. T. M, Edey, T. N. and Hill, M. K. 1975. In: Meat Animal Science. pp. 169-240.

Ying, J. 1986. Some goat breeds (China). World Anim. Review. 58 : 31-41. 